\title{
Selvmord sett fra innsiden
}

\author{
Anmeldt av Kim Larsen
}

ET PREMISS for denne boken er nødvendigheten av et fenomenologisk perspektiv - et perspektiv hvor en forsøker å forstå den suicidales unike subjektive opplevelsesverden. Redaktøren utdyper dette slik i forordet:

«Suicide is still very much tied to mental illness and ultimately considered only a complication of such conditions. A phenomenological approach is still lacking and the opportunity to understand the suicidal mind still impaired. Too often health professionals are focused on what is simpler, that is treat a medical or mental illness, whereas facing suicide risk goes beyond the traditional approach and involves human understanding of suffering in a specific individual. A shift in paradigm is needed; such a novel approach is more complicated, but nevertheless cost-effective» (s. vii-viii).

Bidragsyterne til boken har alle sine spesielle temaer og innfallsvinkler, men en fellesnevner er at de ser det som essensielt å se den suicidales opplevelsesverden «innenfra», både for teoretisk forståelse av hvordan den suicidale prosess har oppstått og for psykoterapeutisk praksis. Det er en betydelig spredning i de tretten kapitlenes tematikk.
Etter tre kapitler som overbevisende argumenterer for nødvendigheten av en fenomenologisk tilnærming, består resten av boken tematisk av to hovedkategorier, og mange av kapitlene kombinerer disse to hovedtemaene. På den ene siden får vi kapitler om den suicidale bevissthet analysert i lys av aversive oppvekstvilkår («early life adversary») ut fra et epigenetisk perspektiv (kapittel 4), tilknytningsteori (kapittel 7), emosjonell dysregulering (kapittel 8), traumer (kapittel 9), og dissassosiasjon (kapittel 10). Vi får også en fortelling fra en person som har overlevd et alvorlig selvmordsfors $ø \mathrm{k}$, om hvordan den suicidale prosess utviklet seg over år, på en måte som var vanskelig å fange opp for omgivelsene (kapittel 12). Det andre hovedtemaet i boken er psykoterapi, psykoterapeutens opplevelse i møtet med suicidale pasienter, og karakteristiske måter suicidalitet kan påvirke den psykoterapeutiske interaksjonen på (kapittel 5, 6 og 11). Vi får også en presentasion av psykoterapiformer som er vinklet spesielt mot suicidalitet og som baserer seg på en fenomenologisk grunnforutsetning; psykodynamisk psykoterapi, kognitiv adferdsterapi, dialektisk adferdsterapi, mentalisering og CAMS («Collaborative Asessment and Magagement of Suicidality»). Boken avsluttes med et gienopptrykk av en artikkel av Edwin Shneidman hvor han oppsummerer sin psykologiske teori om selvmord (kapittel 13).

I innføringstekster om suicidologi som vitenskap er det vanlig å betone selvmord som et multifaktorielt fenomen, med kategorier av årsaker som strekker seg fra genetikk (monozygote tvillinger har høyere konkordans for selvmord enn dizygote) og biologi (personer med suicidal adferd er funnet å ha lavere konsentrasion av serotoninmetabolitten 5HIAA i cerebrospinalvæsken) på den ene siden,

\section{Når det gielder hvilke psykologiske faktorer som er mest avgiorende har oppfatningen forandret seg markant.}

via psykologi (Freud, Shneidman) og sosiologi (Durkheim), til kultur (land som har høyere aksept for selvmord har høyere selvmordsrater) og filosofi (Camus) som det andre ytterpunktet.

I denne multifasetterte «vifteformen» av årsaker vil vel de psykologiske faktorene fremstå som de mest umiddelbare årsaker («pro- 


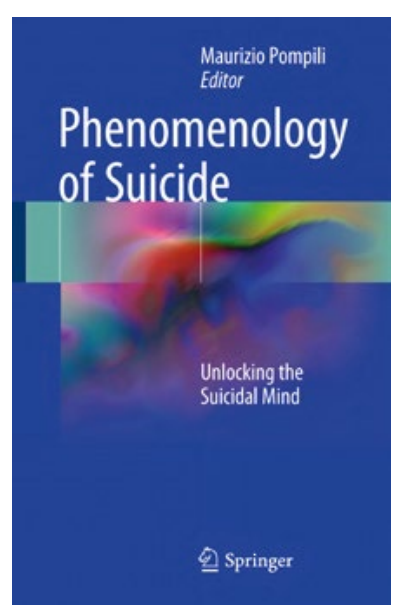

MAURIZIO POMPILI (RED.):

Phenomenology of suicide.

Unlocking the suicidal mind.

Springer International Publishing. 2018.

ISBN: 978-3-319-47975-0

227 sider ximate causes») til selvmordet. I siste instans blir selvmordet drevet frem av psykologiske faktorer, som for eksempel individets intense emosjonelle smerte kombinert med en opplevelse av at alt er håpløst og at fremtiden ikke vil kunne endre noe, hverken ytre livsbetingelser eller emosjonell smerte.

Den psykoanalytiske forestillingen om selvmord som aggresjon vendt innover eller som aggresjon rettet mot internaliserte objekter fikk utbredelse i faget med Freuds artikkel Mourning and melancholia (1917), og ble popularisert av Karl Menninger i hans bok Man against himself (1938). Men som tittelen på Freuds artikkel røper handler artikkelen om sorg og melankoli, ikke selvmord. Det er faktisk bare ett eneste avsnitt som omhandler selvmord. Likevel sementerte disse få linjene Freud skrev forestillingen om aggresion som grunnemosionen i selvmord i mange tiår, både i faget og generelt i samfunnet. Den store psykologen i suicidologisk teori er imidlertid Edwin Shneidman (1918-2009). Han legger vekt på helt andre og "motsatte» emosjoner; angst, håpløshet, lidelsestrykk, emosjonell smerte, meningsløshet, ensomhet etc. Jeg tror nok

Shneidman har mest rett. Det er ikke noe problem å finne eksempler på aggressive selvmord, men den typiske emosion er ikke aggresion, men de mer lidelsfylte og «maktesløse» emosjoner Shneidman nevner (se for eksempel Shneidman, 1985; 1993; 1996). Den siste bølgen av psykologisk suicidologisk forskning vektlegger kognitive faktorer i tråd med vår tids overliggende Zeitgeist i psykologifaget (se for eksempel Williams, 2014).

Pheonomenology of suicide. Unlocking the suicidal mind bygger på fenonomenologi som et avgiørende utgangspunkt for å forstå den idiosynkratiske suicidale opplevelsesverden innenfra og for å omsette denne forståelsen i effektive psykoterapeutiske tiltak, samt en fyldestgiørende forståelse av hvilke utfordringer suicidalitet typisk kan skape for terapeuten i den psykoterapeutiske prosess. Boken er svært vellykket i å argumentere for nødvendigheten av det fenomenologiske perspektiv i suicidologien, uten å bli dogmatisk og uten å angripe suicidologisk forskning og praksis som utgår fra andre forutsetninger. Boken gir også tallrike eksempler og nyttige praktiske råd i psykoterapi, slik at en kan unngå noen av de fallgruver som psykoterapi med suicidale pasienter ofte åpner for.

Phenomenology of suicide. Unlocking the suicidal mind kan varmt anbefales til alle psykoterapeuter siden det å møte suicidalitet i praksis er uunngåelig. Boken forener en fruktbar teoretisk forståelse med praktisk nyttige råd. Årets bok i suicidologi i 2018?

\section{REFERANSELISTE:}

Freud, S. (1917). Mourning and melancholia. I The Standard Edition of the Complete Psychological Works of Sigmund Freud. Oversatt og redigert av James Strachey. London: Hogarth Press. 1974. Vol. 14, S. 237-258.

Menninger, K. (1938). Man against himself. London: Harcourt Brace Iovanovich.

Shneidman, E.S. (1985) Definition of suicide. Oxford: Jason Aronson.

Shneidman, E.S. (1993). Suicide as psychache. A clinical approach to self-destructive behavior. Plymouth: Iason Aronson.

Shneidman, E.S. (1996). The suicidal mind. Oxford: Oxford University Press.

Williams, M. (2014). The cry of pain. Understanding suicide and the suicidal mind. [Oppdatert og revidert utgave av Cry of Pain (1997)]. London: Piatkus. 